\title{
Analisis Faktor-Faktor yang Mempengaruhi Minat UMKM Terhadap Penggunaan Uang Elektronik Di Kota Padang Reno Fithri Meuthia ${ }^{1}$, Rangga Putra Ananto ${ }^{2}$, dan Zalida Afni ${ }^{3}$ \\ 1 Jurusan Akuntansi , Politeknik Negeri Padang \\ Email : enofm87@gmail.com \\ 2 Jurusan Akuntansi, Politeknik Negeri Padang \\ Email: rangga_delavega@yahoo.com \\ 3 Jurusan Akuntansi, Politeknik Negeri Padang \\ Email: zalida.afni@yahoo.com
}

\begin{abstract}
The purpose of the study is to identify the intention to use e-money for SME owners in Padang, West Sumatra. We used the modification of UTAUT model and added Power Distance and Long Time Orientation as new variables. Data were gathered from 128 SME owners who never use e-money in their business activities. Data obtained were analyzed using multiple linear regression analysis for hypotheses testing. The results showed that Social Influence was the most strongly affected behavioral intention to use e-money followed by Performance Expectancy, Power Distance and Effort Expectancy.
\end{abstract}

Keywords : E-money, SME, UTAUT, Padang

\begin{abstract}
ABSTRAK
Penelitian ini bertujuan untuk mengetahui faktor-faktor yang mempengaruhi minat pelaku UMKM Kota Padang dalam menggunakan uang elektronik sebagai alat pembayaran. Model penelitian merupakan modifikasi dari model UTAUT dengan menambahkan dua variabel baru yaitu Power Distance dan Long Time Orientation yang diambil dari unsur budaya menurut Hofstede. Pengumpulan data menggunakan metode random sampling dengan jumlah responden sebanyak 128 pelaku UMKM di Kota Padang. Teknik analisa data menggunakan regresi berganda dengan menggunakan SPSS. Hasil dari penelitian ini menunjukkan bahwa variabel Social Influence, Performance Expectancy, Effort Expectancy dan Power Distance merupakan faktor-faktor yang mempengaruhi minat pelaku UMKM untuk menggunakan uang elektronik di Kota Padang.
\end{abstract}

Kata kunci: Uang Elektronik, E-Money, UMKM, UTAUT, Kota Padang

\section{Pendahuluan}

Penggunaan uang elektronik saat ini sudah menyebar diseluruh dunia. Hal ini sejalan dengan aktifnya penggunaan telpon genggam yang menawarkan beragam fitur termasuk penggunaan uang elektronik. Trend penggunaan uang elektronik ini juga mulai ramai di Indonesia, khususnya kota-kota besar. Sejak diperkenalkan pada tahun 2007 uang elektronik diklasifikasikan ke dalam produk berbasis kartu dan produk berbasis perangkat lunak. Layanan uang elektronik telah meningkat di Indonesia, tidak hanya disediakan oleh bank dan perusahaan telekomunikasi, pengembang aplikasi juga mengambil bagian dalam pembayaran elektronik. Uang elektronik berbasis perangkat lunak biasanya berbentuk aplikasi seperti Gopay, OVO atau LinkAja, sedangkan uang elektronik berbasis chip umumnya berbentuk seperti kartu seperti Flazz dan Brizzi. 
Uang elektronik (e-money) adalah inovasi keuangan baru untuk transaksi pembayaran di Indonesia. Aturan tentang e-money terdapat dalam Peraturan Bank Indonesia Nomor: 11/12/PBI/2009 tentang Uang Elektronik (Electronic Money) yang kemudian diperbarui menjadi PBI Nomor: 18/ 17/PBI/2016, menyebutkan bahwa $e$ money diterbitkan atas dasar nilai uang yang disetor terlebih dahulu oleh pemegang kepada penerbit dan nilai uang tersebut disimpan secara elektronik dalam suatu media seperti server atau chip. E-money bukan hanya sebagai pengganti uang tunai fisik dalam bentuk koin dan uang kertas dengan uang elektronik yang setara, namun juga sebagai sebuah sistem yang memungkinkan seseorang untuk membayar barang atau jasa dengan mengirimkan nomor dari satu komputer ke komputer lain. Kemunculan $e$ money di tengah-tengah masyarakat sebagai instrumen pembayaran mikro bertujuan untuk mengurangi biaya pencetakan uang, keamanan dan risiko hilang, dan untuk memberikan kemudahan dalam transaksi bagi pelanggan (Bank Indonesia, 2006).

Namun demikian, setelah sepuluh tahun diperkenalkan kepada masyarakat, penggunaan uang elektronik masih sangat rendah. Berdasarkan survei elektronik Daily Social pada tahun 2017, hampir 30\% responden tidak pernah menggunakan uang elektronik dalam bentuk apa pun. Hal ini sejalan dengan hasil penelitian Lani Miliani dkk (2013) yang menemukan meskipun pertumbuhan uang elektronik dalam bentuk kartu telah cukup banyak, tetapi penggunaan secara individual masih sangat rendah dibandingkan dengan total penduduk seluruh Indonesia.

Seiring dengan banyaknya penawaran uang elektronik di Indonesia, maka penelitian tentang penggunaan uang elektronik juga telah banyak dilakukan. Dari beberapa penelitian terdahulu terlihat bahwa sebagian besar penelitian membahas tentang faktor-faktor penerimaan penggunaan uang elektronik yang dilihat dari sisi konsumen (Lani Miliani dkk, 2013 ; Wasisto Raharjo Jati, 2015, Ratna Dzulhaida dkk, 2018), penggunaan e-money dikalangan mahasiswa atau generasi milenial (Laila Ramadani, 2016) dan penggunaan uang elektronik untuk pembayaran transportasi (Wibowo dkk, 2015).

Terdapat beberapa kesimpulan menarik atas faktor-faktor yang mempengaruhi penggunaan uang elektronik di Indonesia. Pertama, penelitian yang dilakukan Wasisto Raharjo Jati (2015) mengungkapkan bahwa pengguna uang elektronik di Indonesia didominasi oleh masyarakat kelas menengah. Dalam penelitiannya Wasisto menemukan bahwa kehadiran uang elektronik mendorong perilaku konsumtif masyarakat golongan menengah. Hal ini dipicu oleh berbagai promo/cashback yang ditawarkan oleh operator uang elektronik yang bekerja sama dengan merchant yang terdapat diberbagai pusat perbelanjaan. Hasil yang sama juga berlaku untuk kalangan mahasiswa. Laila Ramadani (2016) yang meneliti pengaruh penggunaan e-money terhadap pengeluaran konsumsi mahasiswa di Malang, menemukan bahwa adanya kartu e-money berpengaruh signifikan terhadap pengeluaran konsumsi mahasiswa. Kedua, berbeda dengan hasil temuan dinegara-negara lain, faktor keamanan/risiko penggunaan uang elektronik tidaklah menjadi penghambat bagi sebagian besar konsumen di Indonesia. Beberapa penelitian yang memasukkan variabel keamanan/risiko bertransaksi pada e-money, menunjukkan hasil faktor keamanan/risiko merupakan variabel yang paling lemah pengaruhnya atau bahkan tidak berpengaruh terhadap penggunaan e-money (Ratna Dzulhaida dkk, 2018, Lani 
Miliani dkk, 2013). Ketiga, faktor utama penyebab kurangnya penggunaan uang elektronik di Indonesia adalah kurangnya informasi mengenai uang elektronik kepada masyarakat (Lani Miliani dkk, 2013).

Untuk meningkatkan penggunaan pembayaran elektronik, pada Oktober 2017, pemerintah Indonesia menyatakan bahwa semua transaksi jalan tol harus sepenuhnya dilakukan secara elektronik. Tindakan ini diambil karena pemanfaatan uang elektronik secara individual masih rendah dibandingkan dengan total populasi Indonesia. Akibat kebijakan pemerintah tersebut, Bank Indonesia (BI) mencatat sampai Agustus 2018 transaksi uang elektronik melonjak lebih dari 300\%. Hal ini terungkap dalam data transaksi uang elektronik terbaru yang dikeluarkan oleh BI. Sementara volume transaksi uang elektronik sampai Agustus 2018 sebesar 297,4 juta transaksi atau naik $375 \%$ secara tahunan dari periode sama tahun lalu yang hanya 62 juta transaksi. Dari sisi nilai, sampai Agustus 2018, tercatat nominal transaksi uang elektronik mencapai Rp 3,8 triliun atau naik 393\% dari periode yang sama tahun lalu Rp 790 miliar. Selanjutnya Pemerintah melalui Kementerian Komunikasi dan Informatika (Kemkominfo) pun ikut mendorong agar para pelaku UMKM di seluruh Indonesia bisa menggunakan sistem pembayaran digital.

Dari uraian diatas dapat dilihat bahwa penggunaan uang elektronik di Indonesia masih terdapat dikota-kota besar, yang umumnya digunakan oleh kaum menengah dan dari kalangan anak muda. Untuk penggunaan secara luas, uang elektronik masih belum terlalu umum digunakan oleh masyarakat Indonesia. Untuk mengetahui penggunaan uang elektronik dikalangan UMKM, maka kami menggunakan modifikasi model The Unified Theory of Acceptance and Use Technology (UTAUT) yang diperkenalkan oleh Venkantesh (2013). Terdapat empat konstruk utama yang memainkan peran penting sebagai determinan langsung dari behavioral intention dan use behavior yaitu, performance expectancy, effort expectancy, social influence, dan facilitating conditions.

Berdasarkan latar belakang yang telah dipaparkan, tujuan penelitian ini adalah untuk mengetahui faktor-faktor apa saja yang mempengaruhi minat pelaku UMKM untuk menggunakan e-payment di Indonesia dengan menggunakan modifikasi model The Unified Theory of Acceptance and Use Technology (UTAUT). Hasil penelitian ini diharapkan dapat menambah pemahaman atas perilaku penerimaan e-money di Indonesia, khususnya dikalangan UMKM di Kota Padang.

\section{Kajian Teori \\ Definisi E-money (Uang Elektronik)}

Menurut peraturan Bank Indonesia No. 11/12/PBI/2009, uang elektronik adalah alat pembayaran yang memenuhi unsur-unsur berikut :

a. Diterbitkan atas dasar nilai uang yang disetor terlebih dahulu oleh pemegang kepada penerbit

b. Nilai uang disimpan secara elektronik dalam suatu media seperti chip atau server

c. Digunakan sebagai alat pembayaran kepada pedagang yang bukan merupakan penerbit uang elektronik tersebut

d. Nilai uang elektronik yang disetor oleh pemegang dan dikelola oleh penerbit bukan merupakan simpanan sebagaimana yang dimaksud dalam undang-undang yang mengatur mengenai perbankan 
Dari definisi diatas dapat disimpulkan bahwa uang elektronik adalah alat pembayaran yang digunakan untuk transaksi secara elektronik melalui jaringan komputer dan internet. Uang elektronik dikeluarkan oleh penerbit yang merupakan perusahaan perbankan maupun lembaga selain bank (LSB). Uang elektronik memiliki nilai uang yang disimpan secara elektronik pada suatu media server atau chip yang dapat dipindahkan untuk kepentingan transaksi pembayaran dan/atau transfer dana. Nilai uang tersebut dapat ditambah/diisi ulang (top up). Uang elektronik dapat digunakan untuk berbagai macam jenis pembayaran (multi purpose) pada berbagai pedagang (merchant) penjual barang dan/atau jasa yang menerima transaksi pembayaran dari pemegang uang elektronik.

\section{The Unified Theory of Acceptance and Use of Technology (UTAUT)}

The Unified Theory of Acceptance and Use Of Technology (UTAUT) merupakan salah satu model penerimaan teknologi yang mensintetiskan elemen-elemen pada delapan model penerimaan teknologi yang pernah ada yaitu theory of reasoned action (TRA), technology acceptance model (TAM), motivation model (MM), theory of planned behavior (TPB), combined TAM \& TPB, model of PC utilization (MPTU), innovation diffusion theory (IDT) dan social cognitive theory (SCT) untuk memperoleh kesatuan pandangan mengenai penerimaan teknologi terkini (Venkatesh et al., 2003).

Setelah mengevaluasi kedelapan model tersebut, Venkatesh et al. (2003) menemukan tujuh konstruk yang tampak menjadi determinan langsung yang signifikan terhadap behavioral intention atau use behavior dalam satu atau lebih di masing-masing model. Konstruk-konstruk tersebut adalah performance expectancy, effort expectancy, social influence, facilitating conditions, attitude toward using technology, dan self-efficacy. Setelah melalui pengujian lebih lanjut, ditemukan empat konstruk utama yang memainkan peran penting sebagai determinan langsung dari behavioral intention dan use behavior yaitu, performance expectancy, effort expectancy, social influence, dan facilitating conditions. Berikut adalah penjelasan dari masing-masing variabel yang terdapat dalam model UTAUT (Venkantesh et al, 2012).

\section{Performance expectancy}

Performance expectancy merupakan konstruk UTAUT yang ditujukan untuk mengukur tingkat kepercayaan seseorang bahwa dengan menggunakan suatu sistem dapat membantu seseorang tersebut dalam mencapai kinerja pekerjaannya (Vekantesh et al., 2003). Peformance expectancy adalah variabel yang dapat disebut sebagai kemampuan untuk memperoleh manfaat yang signifikan setelah menggunakan sebuah sistem (Adenan, 2015).

\section{Effort Expectancy}

Effort expectancy adalah tingkatan upaya setiap individu dalam penggunaan sebuah sistem untuk mendukung melakukan pekerjaannya (Venkatesh et al., 2003). Menurut Adenan (2015), effort expectancy mengacu pada seberapa mudah seseorang berpikir dalam menggunakan sebuah sistem. Davis (1989) dalam Chang (2012) menemukan bahwa sebuah aplikasi dapat diterima oleh penggunanya ketika sebuah aplikasi tersebut mudah digunakan. 


\section{Social Influence}

Social influence merupakan keadaan sewaktu seseorang butuh mendengarkan pendapat orang lain untuk meyakinkan dirinya ketika menggunakan sistem baru (Venkatesh et al., 2003).

\section{Facilitating Conditions}

Facilitating conditions adalah tingkat keyakinan seseorang bahwa infrastruktur perusahaan dan teknis tersedia untuk mendukung penggunaan sistem (Venkatesh et al., 2003). Perangkat tersebut dapat berupa sistem yang digunakan, pelatihan, buku manual ataupun lainnya (Venkatesh \& Davis, 1996; Adenan, 2015).

\section{Behavioral Intention}

Behavioral intention didefinisikan sebagai ukuran kekuatan niat seseorang untuk melakukan perilaku tertentu. Behavior intention dapat diukur dengan mempertimbangkan kemungkinan bahwa konsumen akan bertindak dengan cara tertentu di masa depan, seperti membeli produk lagi atau merekomendasikan kepada teman (Hoyer dan Macinnis, 2008; Leoman, 2014)

\section{Dimensi Budaya Berdasarkan Teori Hofstede}

Hofstede (2010) memperkenalkan 6 dimensi budaya yang digunakan untuk mengukur dan membandingkan budaya nasional suatu masyarakat. Dimensi-dimensi tersebut adalah sebagai berikut : power distance, individualism vs collectivism, masculinity vs femininity, uncertainty avoidance, long term orientation vs short term orientation, indulgence vs restraint.

Hofstede juga mengembangkan suatu pengukuran nilai-nilai budaya suatu negara dibandingkan dengan negara lain. Berikut adalah hasil penilaian dimensi budaya masyarakat Indonesia berdasarkan metode Hofstede (gambar 1).

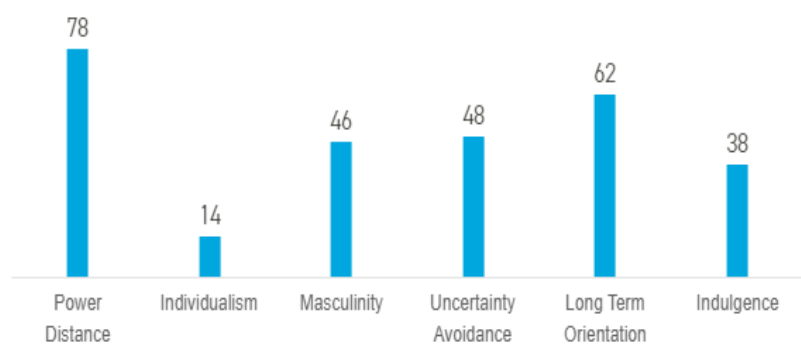

Gambar 1 : Dimensi Budaya Masyarakat Inddonesia Hofstede (2010)

Dari grafik diatas terlihat bahwa Indonesia memiliki nilai yang cukup tinggi pada dua dimensi budaya, yaitu power distance (78) dan long term orientation (62). Sementara pada empat dimensi yang lain, nilai Indonesia termasuk rendah yaitu uncertainty avoidance (48), masculinity (46), indulgence (38), dan nilai paling rendah berada pada dimensi budaya individualism (14). 
Tingginya nilai power distance menunjukkan bahwa umumnya masyarakat Indonesia memiliki sifat taat kepada atasan. Budaya yang umumnya berlaku atasan memberikan perintah kepada bawahan dan kemudian bawahan menjalankan perintah sesuai dengan arahan atasan. Selanjunya dimensi long term orientation juga memiliki nilai yang cukup tinggi, artinya masyarakatnya cenderung dapat beradaptasi dengan perubahan lingkungan dibandingkan dengan masyarakat yang memiliki nilai rendah pada dimensi long term orientation.

Rendahnya nilai dimensi individualism dan indulgence menyiratkan bahwa masyarakat Indonesia cenderung hidup kolektif. Masyarakat lebih senang berada dalam kelompok dan menjunjung nilai-nilai yang dianut kelompoknya. Masyarakat Indonesia juga cenderung tidak terlalu mementingkan ambisi pribadi dan kebendaan, tetapi mementingkan harmoni dengan lingkungan sekitar, yang tercermin dari rendahnya nilai dimensi masculinity dan uncertainty avoidance.

Untuk kepentingan penelitian ini, peneliti hanya akan memasukkan dimensi budaya yang memiliki nilai yang cukup signifikan, yaitu power distance dan long term orientation kedalam model yang akan dirancang.

\section{Pengertian dan Klasifikasi UMKM}

Pengertian UMKM sebagaimana yang tertuang dalam Kepres RI No. 19 Tahun 1998, adalah suatu kegiatan ekonomi rakyat pada skala kecil yang perlu dilindungi dan dicegah dari persaingan yang tidak sehat. Berdasarakan peraturan perundangundangan No. 20 tahun 2008, maka kriteria UMKM dibedakan secara masing-masing meliputi usaha mikro, usaha kecil, dan usaha menengah. Berikut adalah pembagian kriteria untuk usaha mikro, kecil dan menengah :

Usaha yang termasuk kriteria usaha mikro adalah usaha yang memiliki kekayaan bersih mencapai Rp 50.000.000,- dan tidak termasuk bangunan dan tanah tempat usaha. Hasil penjualan usaha mikro setiap tahunnnya paling banyak Rp 300.000.000,-

Usaha yang masuk kriteria usaha kecil adalah usaha yang memiliki kekayaan bersih Rp 50.000 .000 ,- dengan maksimal yang dibutuhkannya mencapai Rp 500.000.000,-. Hasil penjualan bisnis setiap tahunnya antara Rp 300.000.000,- sampai Rp 2.500.000.000,-.

Usaha menengah sering dikategorikan sebagai bisnis besar dengan kriteria kekayaan bersih yang dimiliki pemilik usaha mencapai lebih dari Rp500.000.000,- hingga Rp10.000.000.000,- dan tidak termasuk bangunan dan tanah tempat usaha. Hasil penjualan tahunannya mencapai Rp 2.500.000.000,- sampai Rp50.000.000.000,-.

Berdasarkan uraian teori diatas maka didapat kerangka pemikiran penelitian sebagai berikut : 


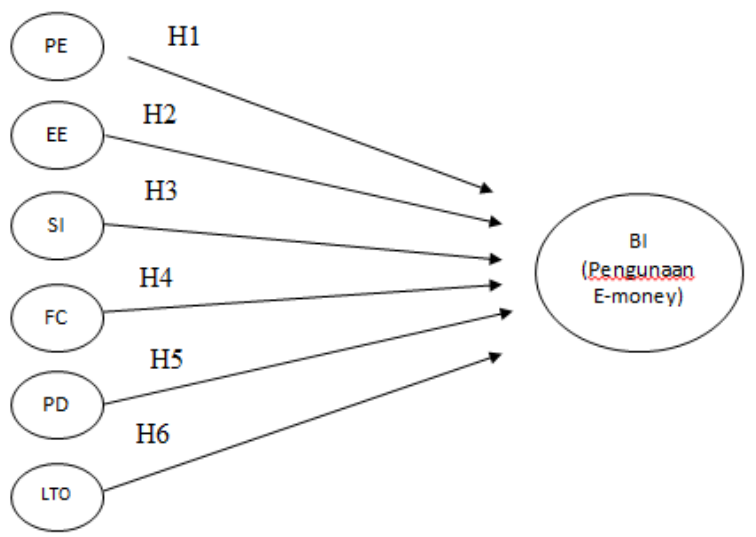

Gambar 2 : Kerangka Pemikiran

Berdasarkan kerangka pemikiran diatas, maka hipotesis dalam penelitian ini adalah sebagai berikut :

H1: Performance Expectancy mempunyai pengaruh yang signifikan terhadap behavioral intention

H2: Effort Expectancy mempunyai pengaruh yang signifikan terhadap behavioral intention

H3: Social Influence mempunyai pengaruh yang signifikan terhadap behavioral intention

H4: Facilitating Condition mempunyai pengaruh yang signifikan terhadap behavioral intention

H5: Power Distance mempunyai pengaruh yang signifikan terhadap behavioral intention

H6: Long Time Orientatation mempunyai pengaruh yang signifikan terhadap behavioral intention

\section{Metode Penelitian}

Penelitian ini berusaha melihat bagaimana adopsi teknologi e-money untuk UMKM di Kota Padang dengan menggunakan pendekatan kuantitatif. Data yang digunakan dalam penelitian ini berasal dari data primer yang diperoleh dari hasil penyebaran kuesioner kepada pelaku UMKM di Kota Padang. Variabel yang digunakan pada penelitian ini dirancang berdasarkan variabel dan indikator yang terdapat pada model UTAUT dan penelitian-penelitian sebelumnya ; performance expectancy (PE), effort expectancy (EE), social influence (SI), dan facilitating conditions (FC), behavior intention (BI), long time orientation (LTO), power distance (PD) dam behavioral intention (BI). Kuesioner penelitian terdiri dari dua bagian yaitu data demografi responden dan pertanyaan yang terkait dengan variabel penelitian. Item pertanyaan pada kuesioner terdiri dari 21 pertanyaan yang diukur dengan skala Likert yang menggunakan 5 opsi jawaban, mulai dari sangat tidak setuju sampai dengan sangat setuju. Kueisoner disebarkan langsung dengan menemui para pelaku UMKM di Kota Padang pada bulan Oktober 2019.

Responden penelitian ini adalah pelaku UMKM yang telah mengetahui mengenai emoney tetapi belum menggunakan e-money sebagai alat pembayaran sebanyak 128 orang. 
Tahapan pertama penelitian adalah pengujian instrumen untuk mengetahui kualitas instrumen yang digunakan dalam penelitian. Peneliti mengambil 30 responden untuk mengisi kuesioner uji coba sebelum pengambilan sampel sejumlah 128 responden. Teknik uji validitas pada penelitian ini menggunakan korelasi Pearson, sedangkan untuk teknik uji reliabilitas menggunakan Cronbach Alpha. Penelitian ini menggunakan teknik analisis regresi berganda untuk menguji pengaruh hubungan antar variabel.

\section{Hasil dan Pembahasan}

Pada bagian pertama kuesioner berisikan aspek demografis responden pelaku UMKM yang terdiri dari informasi mengenai jenis bidang usaha, jumlah omzet perbulan dan metode pembayaran yang dilakukan saat ini. Dibawah ini adalah ringkasan mengenai karakterisktik responden penelitian :

Tabel 1 : Data Demografi Responden

\begin{tabular}{lrr}
\hline Karakteristik Responden & Persentase & Jumlah \\
\hline Bidang usaha : & & \\
Sandang & 12.5 & 16 \\
Pangan & 82.8 & 106 \\
Perabot & 4.7 & 6 \\
& & \\
Omzet : & & 90 \\
<Rp. 25 juta / bulan & 70.3 & 38 \\
Rp. 25 - 50 juta / bulan & 29.7 & \\
& & 16 \\
Metode Pembayaran : & & \\
Tunai & 87.5 & 112 \\
Kartu Debit/Kredit & 12.5 & \\
\hline
\end{tabular}

Berdasarkan tabel diatas, terlihat bahwa sebagian besar responden merupakan pelaku usaha berskala kecil (70.3\%) yang bergerak dibidang usaha makanan (82.8\%) yang masih mengandalkan uang tunai dalam transaksi sehari-hari (87.5\%).

Hasil uji validitas menggunakan koefisien korelasi Product Moment menunjukkan bahwa nilai koefisien korelasi setiap item pertanyaan menunjukkan hasil yang yang lebih besar daripada $r$ hitung (0.172). Hal ini menunjukkan seluruh butir pertanyaan pada kuesioner adalah valid. Hasil uji reliabilitas (lihat tabel 2) menunjukkan bahwa instrumen variabel performance expectancy (PE), effort expectancy (EE), social influence (SI), dan facilitating conditions ( $F C$ ), behavior intention (BI), long time orientation (LTO), power distance (PD) dam behavioral intention (BI) yang terdiri dari 21 butir pertanyaan memiliki koefisien Alpha Cronbach lebih besar dari 0.6. Hal ini menunjuukan bahwa semua variabel pada penelitian ini adalah reliabel.

Tabel 2 : Hasil Uji Reliabilitas

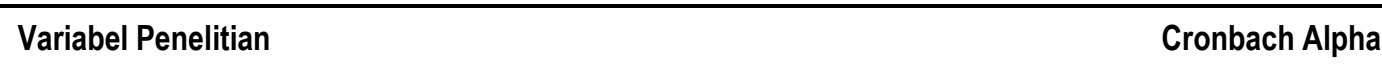




\begin{tabular}{lll}
\hline Variabel Independen : & Performance Expectancy (PE) & 0.791 \\
& Efford Expectancy (EE) & 0.659 \\
& Social Influence (SI) & 0.704 \\
& Facilitating Condition (FC) & 0.718 \\
& Power Distance (PD) & 0.672 \\
& Long Time Orientation (LTO) & 0.624 \\
Variabel Dependen : & Behavioral Intention (BI) & 0.652
\end{tabular}

Hasil uji multikolinieritas menunjukkan bahwa tidak terdapat multikolinieritas karena semua nilai Tolerance diatas 0.1 dan semua nilai VIF dibawah 10. Hasil lebih rinci dapat dilihat pada tabel dibawah ini :

Tabel 3 : Uji Multikolinearitas

\begin{tabular}{lcc}
\hline & Tolerance & VIF \\
\hline Performance Expectancy (PE) & 0.867 & 1.153 \\
Efford Expectancy (EE) & 0,767 & 1.304 \\
Social Influence (SI) & 0.477 & 2.095 \\
Facilitating Condition (FC) & 0.438 & 2.286 \\
Power Distance (PD) & 0.984 & 1.016 \\
Long Time Orientation (LTO) & 0.959 & 1.042 \\
\hline
\end{tabular}

Untuk menguji hipotesis penelitian, digunakan regresi berganda untuk melihat nilai beta untuk mengukur pengaruh antara variabel intention to use e-money (variabel dependen) dan enam variabel independen lainnya yaitu performance expectancy (PE), effort expectancy(EE), social influence (SI), facilitating conditions (FC), power distance (PD) dan long time orientation (LTO). Dari hasil regresi diketahui nilai R square adalah 0.636 artinya variabel performance expectancy (PE), effort expectancy (EE), social influence (SI), facilitating conditions ( FC), power distance (PD) dan long time orientation (LTO) secara simultan berpengaruh terhadap variabel behavioural intention sebesar $63.6 \%$, sedangkan sisanya sebesar $36.6 \%$ diperngaruhi oleh variabel-variabel lain yang tidak dimasukkan kedalam model. Hasil regresi berganda yang dilakukan dapat dilihat pada tabel berikut :

Tabel 4 : Hasil Regresi

\begin{tabular}{lccc}
\hline Variabel & Beta & t-value & Sig \\
\hline Konstanta & 0.791 & & \\
Performance Expectancy (PE) & 0.328 & 4.355 & 0.000 \\
Effort Expectancy (EE) & 0.170 & 2.121 & 0.036 \\
Social Influence (SI) & 0.548 & 5.392 & 0.000 \\
Facilitating Condition (FC) & 0.018 & 0.167 & 0.867 \\
Power Distance (PD) & 0.214 & 3.030 & 0.003 \\
Long Time Orientation (LTO) & 0.039 & 0.551 & 0.582 \\
\hline
\end{tabular}


Tabel 5 : Kesimpulan dari Uji Hipotesis

\begin{tabular}{ccc}
\hline Variabel & Hipotesis & Kesimpulan \\
\hline $\mathrm{PE}>\mathrm{BI}$ & $\mathrm{H} 1$ & $\mathrm{H} 1$ Diterima \\
$\mathrm{EE}>\mathrm{BI}$ & $\mathrm{H} 2$ & $\mathrm{H} 2$ Diterima \\
$\mathrm{SI}-\mathrm{BI}$ & $\mathrm{H} 3$ & $\mathrm{H} 3$ Diterima \\
$\mathrm{FC}-\mathrm{BI}$ & $\mathrm{H} 4$ & H4 Ditolak \\
$\mathrm{PD}->\mathrm{BI}$ & $\mathrm{H} 5$ & $\mathrm{H} 5$ Diterima \\
$\mathrm{LTO}->\mathrm{BI}$ & $\mathrm{H} 6$ & $\mathrm{H} 6$ Ditolak \\
\hline
\end{tabular}

Berdasarkan hasil statistik pada tabel 4, terlihat bahwa variabel performance expectancy, effort expectancy, social influence dan power distance memiliki pengaruh yang signifikan terhadap terhadap variabel behavioral intention $(\mathrm{sig}<0,05)$, sedangkan variabel facilitating condition dan long time orientation tidak berpengaruh signifikan terhadap terhadap variabel behavioral intention (sig $>0,05$ ) yang berarti hipotesis $\mathrm{H} 4$ dan H6 ditolak. Dari hasil regresi tersebut dapat dibuatkan persamaan liniernya sebagai berikut :

$$
Y=0.791+0.328+0.170+0.548+0.018+0.214+0.039
$$

\section{Kesimpulan dan Saran \\ Kesimpulan}

Dari hasil penelitian terlihat bahwa variabel performance expectancy, effort expectancy, social influence dan power distance berpengaruh signifikan terhadap variabel behavioral intention sedangkan variabel facilitating condition dan long time orientation merupakan variabel yang paling lemah pengaruhnya terhadap variabel behavioral intention.

Secara keseluruhan, variabel social influence merupakan variabel yang paling besar pengaruhnya terhadap minat pelaku UMKM untuk menggunakan uang elektronik dalam transaksi sehari-hari (Beta=0,548). Artinya, pelaku UMKM di Kota Padang masih memerlukan dorongan dari lingkungan sekitar untuk menggunakan uang elektronik. Ketika pelaku UMKM melihat bahwa masih banyak perusahaan sejenis yang bertransaksi menggunakan uang tunai, maka mereka pun merasa belum perlu untuk menggunakan uang elektronik. Selain itu dorongan dari konsumen pun bisa menjadi faktor penarik bagi pelaku UMKM untuk menggunakan uang elektronik. Adanya permintaan dari konsumen untuk menerima pembayaran dengan uang elektronik dapat meningkatkan minat pelaku UMKM untuk menggunakan uang elektronik sebagai alat pembayaran.

Variabel lain yang berpengaruh signifikan terhadap minat pelaku UMKM untuk menggunakan uang elektronik adalah performance expectancy (Beta=328), diikuti oleh variabel power distance (Beta $=214$ ) dan effort expectancy (Beta=0,170). Tingginya nilai signifikansi variabel performance expectancy menunjukkan bahwa meskipun saat ini pelaku UMKM belum menggunakan uang elektronik sebagai alat pembayaran, tetapi mereka telah menyadari manfaat menggunakan uang elektronik sebagai salah satu 
alternatif pembayaran. Hal ini disebabkan karena umumnya pelaku UMKM telah atau pernah menggunakan uang elektronik dalam melakukan transaksi sehari-hari.

Sebagaimana yang diungkap oleh Hofstede (2010), salah satu karakteristik masyarakat Indonesia adalah cenderung patuh kepada pihak pemerintah atau pihak berwenang. Hal ini menjadi penjelasan variabel power distance yang berpengaruh signifikan terhadap minat pelaku UMKM dalam menggunakan uang elektronik. Dengan karakter masyarakat seperti ini, peran aktif pemerintah untuk melakukan sosialisasi penggunaan uang elektronik sangat diperlukan.

Hal lain yang masih harus menjadi perhatian adalah tingginya nilai variabel effort expectancy yang artinya pelaku UMKM masih menganggap sulit penggunaan uang elektronik dalam transaksi sehari-hari. Dari beberapa wawancara, terungkap kekhawatiran bahwa uang yang mereka dapat dari transaksi penjualan akan sulit untuk diuangkan dan sulit digunakan untuk berbelanja bahan baku kebutuhan produksi. Kekhawatiran ini dapat diatasi dengan pemberian informasi yang tepat kepada pelaku usaha sehingga dapat meningkatkan minat mereka untuk menggunakan uang elektronik.

Selanjutnya, dari hasil regresi terlihat bahwa variabel facilitating condition dan long time orientation tidak berpengaruh terhadap variabel behavioral intention. Hal ini disebabkan karena pelaku UMKM tidak terlalu peduli kepada sarana pendukung fasilitas uang elektonik. Kemudian, karakter masyarakat Indonesia yang umumnya masih belum bherorientasi masa depan, menjadikan variabel long time orientation juga sangat kecil pengaruhnya terhadap minat pelaku UMKM untuk menggunakan uang elektronik. Sebagian besar responden yang diwawancarai adalah pelaku UMKM dengan omzet yang masih kecil, yaitu dibawah Rp. 25.000.000,- sebulan. Karakter pengusaha kecil seperti ini masih memikirkan waktu saat ini dan belum berpikiran jauh kedepan.

\section{Saran}

\section{Saran bagi Pemerintah/Pihak Terkait}

Faktor lingkungan sosial dan dukungan/campur tangan pemerintah merupakan dua faktor terbesar yang berpengaruh terhadap minat pelaku UMKM untuk mengunakan uang elektronik. Artinya pelaku UMKM perlu didorong untuk menggunakan uang elektronik. Pemerintah, dalam hal ini adalah Dinas Koperasi dan UMKM selaku pembina pengusaha UMKM perlu melakukan tindakan aktif untuk meningkatkan penggunaan uang elektronik sebagai alat pembayaran oleh pelaku bisnis. Dinas Koperasi bersama dengan Bank Indonesia selaku regulator uang elektronik perlu memikirkan cara untuk meningkatkan penggunaan uang elektronik kepada pelaku UMKM. Pemerintah bisa menggandeng operator uang elektronik yang mewajibkan UMKM untuk menerima pembayaran dengan uang elektronik apabila mereka mendaftar sebagai partner pada operator uang elektronik. 


\section{Saran untuk Penelitian Selanjutnya}

Penelitian ini hanya berfokus pada pelaku UMKM di Kota Padang, sehingga untuk penelitian selanjutnya dapat ditambahkan pelaku UMKM di kota-kota besar lain di Sumatera Barat, sehingga didapat gambaran yang lebih menyeluruh atas minat pengusaha UMKM untuk menggunakan uang elektronik sebagai salah satu alternative alat pembayaran.

Berdasarkan hasil penelitian ini, masih terdapat sekitar 36\% faktor-faktor yang tidak dapat dijelaskan dalam model. Hal ini membuka peluang bagi peneliti berikutnya untuk memasukkan faktor-faktor yang diperkirakan akan berpengaruh pada minat pelaku UMKM dalam menggunakan uang elektronik.

\section{Ucapan Terima Kasih (Acknowledgement)}

Terima kasih yang sebesar-besarnya kami haturkan kepada pihak-pihak yang telah membantu membantu kami dalam melakukan penelitian ini, diantaranya Politeknik Negeri Padang sebagai penyandang dana penelitian, Dinas Koperasi Kota Padang sebagai penyedia data dan penghubung kepada para pelaku UMKM, para responden penelitian yang telah meluangkan waktunya untuk wawancara dan mengisi kuesioner, serta sdr Ilham Setiawan yang telah membantu kami sebagai asisten peneliti.

\section{Referensi}

Alshare, K., \& Mousa, A. (2014). The Moderating Effect of Espoused Cultural Dimensions on Consumer's Intention on Use Mobile Payment Device. Auckland: Thirty Fifth International Conference on Information Systems.

Dahlberg, T., Guo, J., \& Ondrus, J. (2015). A Critical Review of Mobile Payment Research.

Ekawati, D. (2018). Analisi Faktor-Faktor yang Mempengaruhi Penggunaan Telkomsel Cash (T-Cash) di Yogyakarta.

Ghozali, I. (2016). Aplikasi Analisis Multivariate dengan Program IBM SPSS 23, Edisi 8. Semarang: Badan Penerbit Universitas DDiponegoro.

Goh, S. (2017). Factos Affecting Adoption of E-Payment Among Private Unversity Students in Klang Valley. Hair, J., Money, A., Samouel, P., \& Page, M. (2006). Research Methods for Business . New York: John Wiley.

Lee, N., \& Kotler, P. (2016). Social Maketing : Changing Behaviors for Good. s. Publication.

Lin , C., \& Nguyen, C. (2011). Exploring e-Payment Adoption in Vietnam and Taiwan .

Miliani, L., Purwanegara, M. S., \& Indriani, M. D. (2013). Adoption Behavior of E-Money Usage. 5(7). Moore, M. (n.d.). Interactive Media Usage Among Millennial Consumers. 29(6).

Pietro, L., Mugion, R., Mattia, G., Renzi, M., \& Toni, M. (2015). The Integrated Model on Mobile Payment Acceptance (IMMPA) : An Empirical Application to Public Transport. 
Schierz, P. G., Schilke, O., \& Wirtz, B. (2010). Understanding Consumer Acceptance of Mobile Payment Services : An Empirical Analysis. 9.

Sekaran, U. (2006). Metodologi Penelitian untuk Bisnis. Jakarta: Salemba Empat.

Suwandi, M. A., \& Azis, E. (2018). Faktor-Faktor yang Mempengaruhi Penggunaan E-Money pada Generasi Milenial.

Venkantesh, V., Morris, M., Davis, G., \& Davis, F. (2003). User Acceptance of Information Technology : Toward a Unified View. 27(3). 